Arch. Tierz., Dummerstorf 46 (2003) 6, 503-512

\begin{abstract}
Indonesian Research Centre and Livestock Development, Bogor, Indonesia ${ }^{1}$. Faculty of Animal Science, Bogor Agricultural University, Indonesia ${ }^{2}$, Institute of Animal Breeding and Genetics with Veterinary Clinic, Martin Luther University, Halle-Wittenberg, Germany ${ }^{3}$
\end{abstract}

\author{
EKO HANDIWIRAWAN ${ }^{1}$, RONNY RACHMAN NOOR ${ }^{2}$, MULADNO $^{2}$ \\ and LUTZ SCHÜLER ${ }^{3}$
}

\title{
The Use of HEL9 and INRA035 Microsatellites as Specific Markers for Bali Cattle
}

\author{
Dedicated to Prof. Dr. sc. Günter Herrendörfer on the occasion of his $65^{\text {th }}$ birthday
}

\begin{abstract}
Bali cattle are one of Indonesian native cattle's that famous for their ability to adapt to tropical harsh conditions. For the last 25 years, indiscriminate crossbreeding using artificial insemination (AI) organizing mainly by government might be has contaminated the purity of Bali cattle. In order to utilize as well as to conserve Bali cattle it is necessary to develop an accurate and simples method to detect the purity of Bali cattle. This experiment is the continuation of a long term experiments in developing methods to detect the purity of Bali cattle i.e. phenotypic variations, blood protein polymorphisms, hair structure, chromosome and DNA microsatellite variation analyses. The specificity of HEL9 and INRA035 microsetellites in Bali cattle as well as in Banteng (Bos sondaicus) as their ancestor was tested.

The results show that A and B alleles at INRA035 microsatellite locus are monomorphic and can be used for a specific markers for Bali cattle. Allele A at locus HEL9 that has high frequency $(92.90 \%)$ in Bali cattle and $100 \%$ in Banteng can also be used as a supporting marker.
\end{abstract}

Key Words: Bali cattle, DNA microsatellite

\section{Zusammenfassung}

Titel der Arbeit: Die Anwendung von Mikrosatelliten HEL9 und INRA035 als spezifische Marker für das Balirind

Das Balirind ist eine einheimische Rasse in Indonesien, die durch seine gute Angepasstheit an tropische Bedingungen gekennzeichnet ist. In den letzten 25 Jahren wurde unter Verwendung der künstlichen Besamung die Kreuzungszucht im Rahmen staatlicher Programme durchgeführt und so die Rasse verändert. Um das Balirind als reine Rasse zu nutzen und diese in Genreserven zu erhalten, sind einfache und genaue Methoden zu entwickeln, um die Reinheit der Balirinder zu überprüfen. Als geeignete Methoden zur Einschätzung der Reinheit der Rasse wurden die phänotypischen Varianzen von Merkmalen, die Blutgruppenpolymorphien, die Haar- und Chromosomenstruktur und die Anwendung von DNA Mikrosatelliten geprüft. Die Spezifität des HEL9 und INRA035 Mikrosatelliten im Balirind ebenso wie im Bantengrind (Bos sondaicus), der Stammform des Balirindes, wurden analysiert.

Die Ergebnisse der Untersuchungen zeigten, dass A und B Allele des INRA035 Mikrosatelliten monomorph sind und für das Balirind verwendet werden können. Das Allel A des HEL9 Mikrosatelliten tritt mit einer Frequenz von $92,40 \%$ im Balirind und mit 100\% im Bantengrind auf und kann als zusätzlicher weiterer Marker genutzt werden.

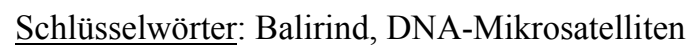

\section{Introduction}

Bali cattle are one of several Indonesian native cattle that plays major role for providing meat. Bali cattle can be found in most parts of Indonesia and they can easily 
adapt new environmental conditions (MARTOJO, 1990). Comparing with other breeds, Bali cattle have better adaptation, especially in poor environment (MASUDANA, 1990), because they can utilize low quality of feedstuffs (SASTRADIPRAJA, 1990), have high reproduction rate (80\% calving percentage), have high carcass percentage (52-57.7\%) (PAYNE and ROLLINGSON, 1973), have high meat quality and low fat percentage (4\%) and resistance to internal and external parasites (PAYNE and HODGES, 1997; NRC, 1983).

Pure breeding of Bali cattle can be found at Bali Island, Sumbawa Island, Flores Island and Bone district of South Sulawesi province (PANE, 1991). Indonesian Government has allocated those islands as the main sources of pure Bali cattle. Crossbreeding can only be conducted outside of areas. However, due to indiscriminate crossbreeding, the pure Bali cattle at those areas have been contaminated with other breeds, i.e. Simmental, Limousine, Brangus, Charolais, indicating by high frequency of abnormal appearances, including abnormal colour patterns and horn shapes. So it is necessary to develop accurate and simple methods that can detect the pure Bali cattle.

The methods for identifying the pure of Bali cattle has been developed and pioneered by NOOR et al. (2000). They used iso-electrical focussing blood protein polymorphism analyses, DNA microsatellite analyses, chromosome structure analyses and hair structure analyses using scanning electron microscope. They suggested that the Bali cattle in Artificial Insemination Centre at Singosari, Malang, West Java and in Bali island might had been contaminated by other species of cattle. However, due to the small sample size used the conclusion has not comprehensive yet.

NOOR et al. (2000) found that out of 15 microsatellite loci tested in Bali cattle, Simmental, Brangus and Limousine, only two loci, i.e. HEL9 and INRA035 were specific for Bali cattle. Based on the result, only these two loci were used in this experiment. WINAYA (2000) using limited number of animal found that HEL9 microsatellite locus is monomorphic in Bali cattle, but not for Madura, Ongole and Brangus breeds. NOOR et al. (2000) were also found the same result using Bali cattle, Simmental, Brangus and Limousine. In addition, INRA035 locus in Bali cattle consistently has two alleles, so it is possible to use both loci as specific markers for Bali cattle. Based on this finding, it is necessary to test the specific alleles using a larger sample at the major areas of Bali cattle distribution in Bali Island. It is expected that the results can be used to differentiate between the pure and un-pure Bali cattle.

\section{Materials and methods}

The whole blood of 300 Bali cattle was randomly collected from 8 major areas of Bali cattle distribution in Bali Island. Blood sample of two Banteng were collected from Ragunan Zoo Jakarta. The locations where the blood sample where collected are shown in Table 1 and Figure 1. HEL9 and INRA035 loci were used and the primer sequences and the size of locus are shown at Table 2.

For each individual, $10 \mathrm{ml}$ of blood sample was taken from vena jugularis using venojeck contain heparin. The sample was stored at mobile cooler contain ice cube $\left(2^{\circ} \mathrm{C}\right)$ and then remains in a low temperature freezer until the DNA was extracted.

Before the blood sample collection was conducted, additional phenotypic information, i.e. colour patterns were also documented. The data then compared with normal colour patterns described by NAMIKAWA et al. (1982) and abnormal colour patterns described by HARDJOSUBROTO and ASTUTI (1993) and MASUDANA (1990). 
Table 1

Locations and number of individuals of whole blood sample collection (Herkunft und Anzahl Tiere mit Blutproben)

\begin{tabular}{lllc}
\hline Locations & \multicolumn{1}{c}{ Samples } & \multicolumn{1}{c}{ Name of Location } & Individuals (heads) \\
\hline 1. & Bali cattle & Siyut village, Gianyar district & 67 \\
2. & Bali cattle & Tulikup village, Gianyar district & 65 \\
3. & Bali cattle & Kesiut village, Tabanan district & 32 \\
4. & Bali cattle & Mengesta village, Tabanan district & 8 \\
5. & Bali cattle & Batumadeg village, Klungkung district & 31 \\
6. & Bali cattle & Klumpu village, Klungkung district & 25 \\
7. & Bali cattle & Denpasar slaughter house & 47 \\
8. & Bali cattle & Ngurah Rai quarantine center, Denpasar & 25 \\
9. & Banteng & Ragunan zoo Jakarta & 2 \\
\hline
\end{tabular}

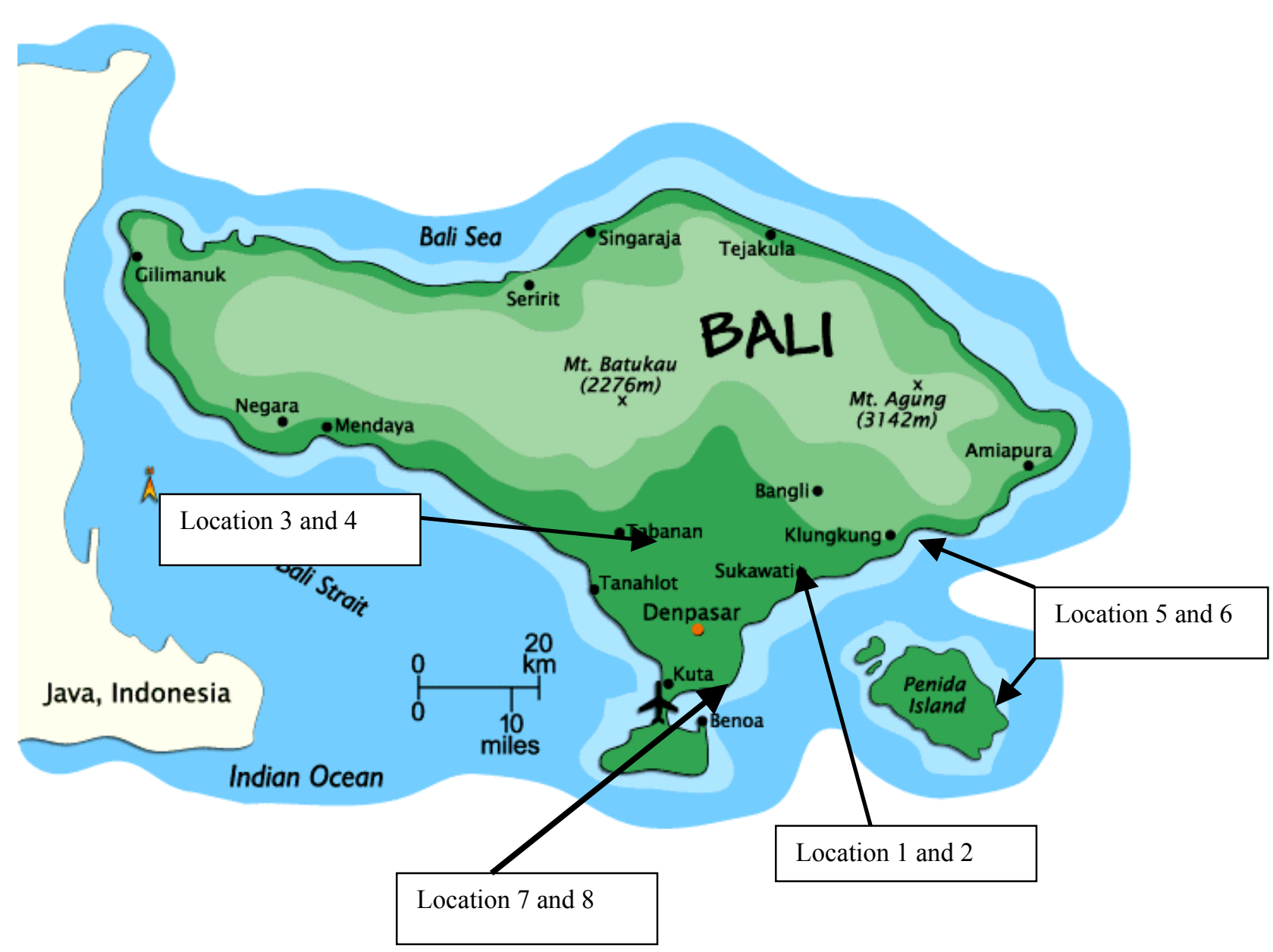

Fig. 1: Location of blood collection (Herkünfte der Blutproben auf Bali)

DNA isolation and extraction were conducted using GenominPrep ${ }^{T M}$ Blood DNA Isolation Kit procedures (product of Amersham Pharmacia Biotech). $50 \mathrm{ng}$ of DNA sample was put into eppendorf PCR tube and mixed with $200 \mathrm{ng}$ primer, $200 \mu \mathrm{M}$ dNTP, $1 \mathrm{x}$ buffer, 1.5 unit taq polymerase enzyme and deionised water until the volume reach $12.5 \mu 1$. One drop of mineral oil then added to the tube. The cycle, temperature and duration of thermal circler are shown in Table 3. 
Table 2

Sequences and the size of HEL9 and INRA035 (Sequenzen und Größe der Mikrosatelliten HEL9 und INRA035)

\begin{tabular}{|c|c|c|c|c|c|}
\hline Loci & Primer sequences $\left(5^{\prime}-3^{\prime}\right)$ & $\begin{array}{l}\text { Number of } \\
\text { allele }\end{array}$ & $\Gamma^{\circ} \mathrm{C}$ & Size (bp) & Sources \\
\hline \multirow[t]{2}{*}{ HEL9 } & F: CCCATTCAGTCTTCAGAGGT & 12 & 55 & $143-$ & Bishop et \\
\hline & R: CACATCCATGTTCTCACCAC & & & 165 & al. (1994) \\
\hline \multirow[t]{2}{*}{ INRA035 } & F: ATCCTTTGCAGCCTCCACATTG & 7 & 55 & 120 & Vaiman et \\
\hline & R: TTGTGCTTTATGACACTATCCG & & & & al. (1994) \\
\hline
\end{tabular}

$\mathrm{F}=$ Forward, $\mathrm{R}=$ Reverse

Table 3

Reaction conditions for amplification of microsatellite (Reaktionsbedingungen für die Amplifizierung der Mikrosatelliten)

\begin{tabular}{ccccc}
\hline Cycle & Steps & $\begin{array}{c}\text { Temperature } \\
\left({ }^{\circ} \mathrm{C}\right)\end{array}$ & Duration (Minutes) & No. of Cycle \\
\hline 1 & 1 & 94 & $05: 00$ & 1 \\
2 & 1 & 94 & $00: 30$ & 35 \\
& 2 & 55 & $00: 30$ & 1 \\
& 3 & 72 & $01: 00$ & - \\
\hline
\end{tabular}

PCR products and microsatellite allele detection were conducted by running the sample on $2 \%$ agarose gel with ethidium bromide colouration. The microsatellite polymorphism was detected by running the PCR product on 5\% acrylamide gel and followed by silver staining procedure.

Allele frequency, the heterozygosity and the variance of heterozygosity for each locus were calculated by using the NEI (1987) and NEI and KUMAR (2000) formula.

\section{Results}

Only some of HEL9 and INRA035 allele were amplified. According to BISHOP et al. (1994), the sequence of HEL9 allele has 143 and $165 \mathrm{bp}$. On the other hand, INRA035 allele has $120 \mathrm{bp}$ (VAIMAN et al., 1994). So based on this standard, HEL9 primer

Table 4

Number of amplified sample using HEL9 primer (Anzahl der amplifizierten Proben des HEL9 Primers)

\begin{tabular}{lccc}
\hline Origin & $\begin{array}{c}\text { Number of sample } \\
\text { positive band }\end{array}$ & $\begin{array}{c}\text { with } \\
\text { number of sample with } \\
\text { negative band }\end{array}$ & Total \\
\hline Tabanan district & 19 & 21 & 40 \\
Klungkung district & 30 & 26 & 56 \\
Gianyar district & 88 & 36 & 124 \\
Slaughter House & 41 & 6 & 47 \\
Quarantine Centre & 16 & 9 & 25 \\
Ragunan Zoo (Banteng) & 2 & 0 & 2 \\
\hline Total & $196(66,7 \%)$ & $98(33,3 \%)$ & 294 \\
\hline
\end{tabular}

has only amplified $66.7 \%$ of the total sample, while INRA035 primer amplified $45.2 \%$ (Table 4 and 5). 
Table 5

Number of amplified sample using INRA035 primer (Anzahl der amplifizierten Proben des INRA035 Primers)

\begin{tabular}{lcccc}
\hline Origin & $\begin{array}{c}\text { Number of sample } \\
\text { positive band }\end{array}$ & $\begin{array}{l}\text { Number of sample with } \\
\text { negative band }\end{array}$ & Total \\
\hline Tabanan district & 8 & 32 & 40 \\
Klungkung district & 26 & 30 & 56 \\
Gianyar district & 48 & 76 & 124 \\
Slaughter House & 31 & 16 & 47 \\
Quarantine Centre & 18 & 7 & 25 \\
Ragunan Zoo (Banteng) & 2 & 0 & 2 \\
Total & $133(45,2 \%)$ & $161(54,8 \%)$ & 294 \\
\hline
\end{tabular}

At HEL9locus, there were four genotypes exist, i.e. $\mathrm{AA}, \mathrm{AB}, \mathrm{AC}$ and $\mathrm{CC}$, where the AA genotype is the most common in Bali cattle. Banteng only has AA genotype in this locus (Table 6).

Table 6

Genotype frequencies at HEL9 locus (Genotypenfrequenz des HEL9 Locus)

\begin{tabular}{|c|c|c|c|c|c|}
\hline No. & Locations & Genotypes & $\begin{array}{l}\text { Number of } \\
\text { Individual (heads) }\end{array}$ & $\begin{array}{l}\text { Genotype } \\
\text { frequencies }\end{array}$ & undetected \\
\hline 1. & Tabanan $^{1)}$ & AA & 4 & 1 & 36 \\
\hline \multirow[t]{4}{*}{2.} & Klungkung $^{1)}$ & AA & 14 & 0,78 & 38 \\
\hline & & $\mathrm{AB}$ & 2 & 0,10 & \\
\hline & & $\mathrm{AC}$ & 1 & 0,06 & \\
\hline & & $\mathrm{CC}$ & 1 & 0,06 & \\
\hline \multirow[t]{3}{*}{3.} & Gianyar $^{1)}$ & AA & 53 & 0,91 & 66 \\
\hline & & $\mathrm{AB}$ & 2 & 0,04 & \\
\hline & & $\mathrm{AC}$ & 4 & 0,05 & \\
\hline \multirow[t]{3}{*}{4.} & Slaughter house ${ }^{1)}$ & AA & 23 & 0,86 & 20 \\
\hline & & $\mathrm{AB}$ & 2 & 0,07 & \\
\hline & & $\mathrm{AC}$ & 2 & 0,07 & \\
\hline \multirow[t]{7}{*}{5.} & Quarantine centre ${ }^{1)}$ & AA & 3 & 0,60 & 20 \\
\hline & & $\mathrm{AB}$ & 1 & 0,20 & \\
\hline & & $\mathrm{AC}$ & 1 & 0,20 & \\
\hline & Total & $\mathrm{AA}$ & 97 & 0,87 & 180 \\
\hline & & $\mathrm{AB}$ & 7 & 0,06 & \\
\hline & & $\mathrm{AC}$ & 7 & 0,06 & \\
\hline & & $\mathrm{CC}$ & 1 & 0,01 & \\
\hline 6. & Ragunan zoo ${ }^{2)}$ & AA & 2 & 1 & 0 \\
\hline
\end{tabular}

There were five genotypes exist at INRA035 locus, i.e. AA, BB, AC, CC and CD. In general Bali cattle has $\mathrm{AB}$ genotypes (89\%) (Table 7). All Banteng only has $\mathrm{AB}$ genotype.

There are some alleles that have high frequency at HEL9 and INRA035 loci. At HEL9 locus, the frequency of allele $\mathrm{A}$ was $92.9 \%$. On the other hand, the frequency of $\mathrm{A}$ and B alleles were $96.8 \%$ and $52.6 \%$ respectively (Table 8 ). Those alleles are also exist in 
Banteng. This result supports the hypothesis that Banteng is the ancestor of Bali cattle because they have common alleles.

Table 7

Genotype frequencies at INRA035 locus (Genotypenfrequenz des INRA035 Locus)

\begin{tabular}{|c|c|c|c|c|c|}
\hline No. & Locations & Genotypes & $\begin{array}{l}\text { Number } \\
\text { individuals } \\
\text { (heads) }\end{array}$ & $\begin{array}{l}\text { of Genotype } \\
\text { frequencies }\end{array}$ & undetected \\
\hline \multirow[t]{3}{*}{1.} & Tabanan ${ }^{1)}$ & $\mathrm{AA}$ & 1 & 0,33 & 37 \\
\hline & & $\mathrm{AB}$ & 1 & 0,33 & \\
\hline & & $\mathrm{CC}$ & 1 & 0,33 & \\
\hline \multirow[t]{2}{*}{2.} & Klungkung ${ }^{1)}$ & AA & 4 & 0,17 & 32 \\
\hline & & $\mathrm{AB}$ & 20 & 0,83 & \\
\hline \multirow[t]{4}{*}{3.} & Gianyar ${ }^{1)}$ & $\mathrm{AA}$ & 1 & 0,03 & 94 \\
\hline & & $\mathrm{AB}$ & 27 & 0,91 & \\
\hline & & $\mathrm{AC}$ & 1 & 0,03 & \\
\hline & & $\mathrm{CD}$ & 1 & 0,03 & \\
\hline 4. & Slaughter house ${ }^{1)}$ & $\mathrm{AB}$ & 9 & 1 & 38 \\
\hline \multirow[t]{6}{*}{5.} & Quarantine centre $^{1)}$ & $\mathrm{AB}$ & 11 & 1 & 14 \\
\hline & Total & AA & 6 & 0,08 & 215 \\
\hline & & $\mathrm{AB}$ & 68 & 0,89 & \\
\hline & & $\mathrm{AC}$ & 1 & 0,01 & \\
\hline & & $\mathrm{CC}$ & 1 & 0,01 & \\
\hline & & $\mathrm{CD}$ & 1 & 0,01 & \\
\hline 6. & Ragunan zoo ${ }^{2)}$ & $\mathrm{AB}$ & 2 & 1 & 0 \\
\hline
\end{tabular}

Table 8

The number of allele, frequency and heterozygosity of HEL9 and INRA035 loci (Anzahl der Allele, Frequenz und Heterozygotie der HEL9 und INRA035 Loci)

\begin{tabular}{lcc}
\hline Parameters & HEL9 locus & INRA035 locus \\
\hline Number of allele & 3 & 4 \\
Frequency of allele A $\left(x_{i}\right)$ & 0,929 & 0,526 \\
Frequency of allele B $\left(x_{i}\right)$ & 0,031 & 0,442 \\
Frequency of allele C $\left(x_{i}\right)$ & 0,040 & 0,026 \\
Frequency of allele D $\left(x_{i}\right)$ & - & 0,006 \\
Degree of monomorphic $(\%)$ & 92,9 & 96,8 \\
Heterozygosity $(\hat{h})$ & 0,135 & 0,530 \\
Heterozygosity variance $\left(V_{s 1}(h)\right)$ & 0,00094 & 0,00024 \\
\hline Average Heterozygosity $(\hat{H})$ & & 0,3325 \\
\hline
\end{tabular}

Based on the colour pattern comparison with previous report, the percentage of abnormal colour pattern is $17 \%$ while the rest have normal colour pattern. The highest number of abnormal colour pattern is the red, brown or black colour in the lower parts of the legs. The colour of these parts for normal colour pattern should be white. The highest number of this abnormal pattern is in Klungkung district. The percentage of 
spotted individuals is $0.67 \%$ and $0.33 \%$ for black coloured female. The normal and abnormal colour patterns are shown in Figure 2.
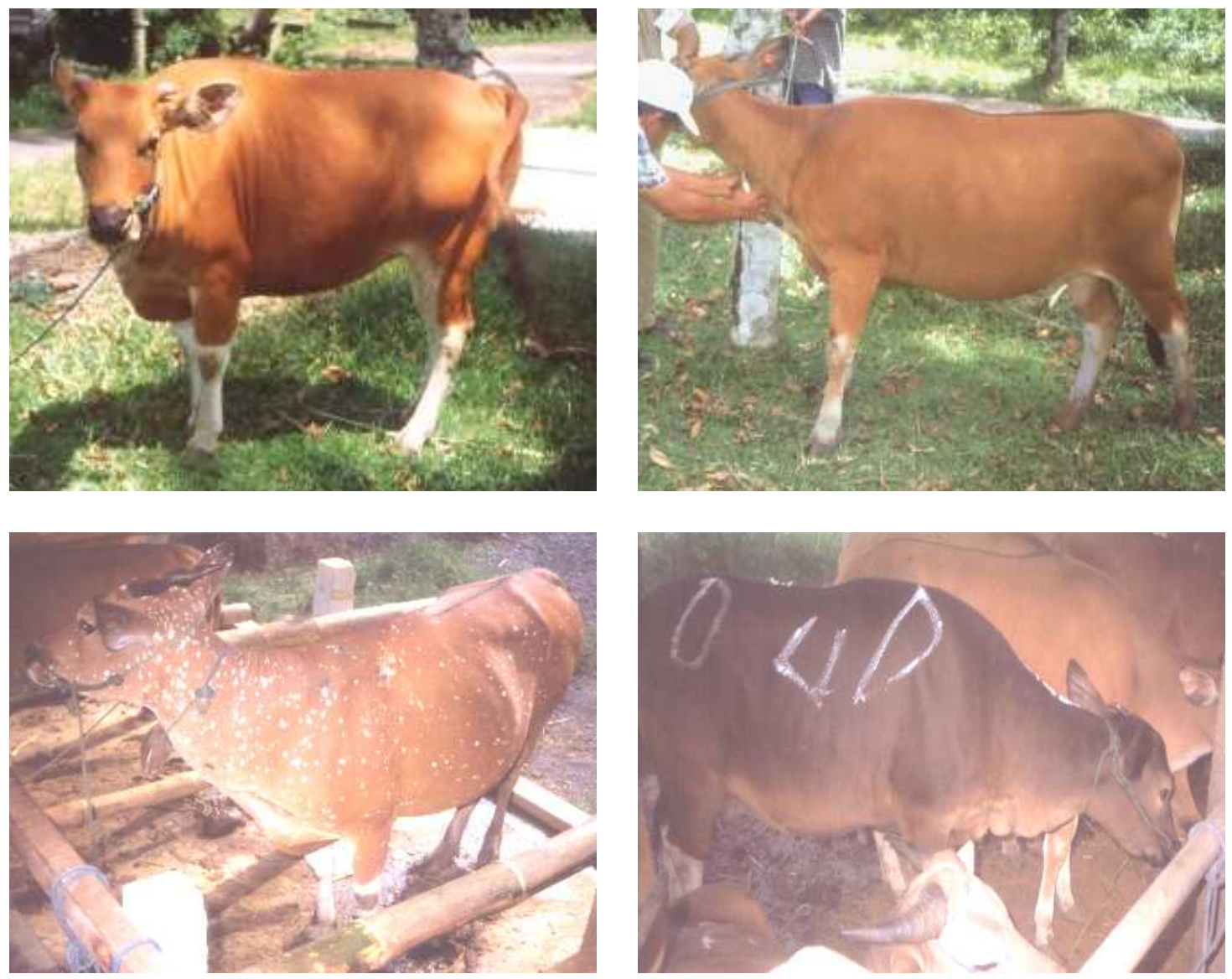

Fig 2: Female with normal colour pattern (top left); Abnormal female colour pattern with brown colour at the lower parts of the legs (top right); spotted female (left below); Black female (bellow right) (Kuh mit Standardfarbe (oben links); Abnormale Fellfarbe mit braunen Flecken an den unteren Beinen (oben rechts);Gefleckte Kuh (unten links); Schwarze Kuh (unten rechts))

\section{Discussion}

Some samples that cannot be amplified by using HEL9 and INRA035 primers could indicate that the individuals do not have HEL9 and INRA035 alleles. The other factors that could cause it, is the existence of null allele phenomena that had been reported by CIAMPOLINI et al. (1995) and LEHMANN et al. (1996). The null allele at microsatellite locus cannot be visualised on gel because of the mutation on the sequence that complement to the primer. As a result this locus cannot be amplified.

The high frequency of the null allele on microsatellite locus has been reported on cattle, human and mosquito. Previous study by using INRA25 microsatellite on four different breeds of cattle indicates the existence of point mutation in null allele with the frequency of $34 \%$ (CIAMPOLINI et al., 1995). In human the existence of null allele accident could reach $30 \%$ ( 7 out of 23 loci). The frequency is even higher in $A$. 
gambiae (mosquito) at locus AG2H46 (LEHMAN et al., 1996). The null allele can cause false genotype because heterozygote individuals are categorized as homozygote because only one allele is amplified.

The result indicates that the alleles of Banteng and Bali cattle are not identical. In Bali cattle there are some alleles that have low frequency. At HEL9 locus, exist B allele that have the size of $\pm 161 \mathrm{bp}$ and $\mathrm{C}$ allele with the size of $\pm 169 \mathrm{bp}$. On the other hand, INRA035 has $\mathrm{C}$ and D alleles that have the size of \pm 121 bp and \pm 138 bp, respectively. It is suggested that these alleles could be the product of mutation due to replication slippage that result a longer sequence (LEVINTON and GUTMAN, 1987; LI and GRAUR, 1991). The other possibility is the existence of gene flow from outside of the population or from other breeds into the population in Bali Island. Other breeds of cattle that commonly present in Indonesia that also has B allele in HEL9 locus are Madura, Ongole, Brangus, Simmental and Limousine. On the other hand, C allele can also be found in Madura and Simmental (WINAYA, 2000 and NOOR et al., 2000). The breed of cattle that also has $C$ allele at INRA035 locus is Madura and Ongole. However, in order to determine whether those alleles are identical with those in Bali cattle, the size of allele should be compared using the same electrophoresis medium i.e. polyacrylamide gel.

The previous experiment result indicated that the A allele at HEL9 locus is monomorphic (all Bali cattle has AA genotype) (WINAYA, 2000; NOOR et al., 2000). The same result is also found for INRA035 locus, because all Bali cattle have AB genotype (WINAYA, 2000). These two loci are excellence candidate to be retested in this experiment to determine whether they are specific allele in Bali cattle. According to HARTL and CLARK (1989), if the number of allele is $\geq 0.95$, then this allele can be categorize as monomorphic and specific. In this experiment, the A and $\mathrm{B}$ alleles at INRA035 locus are monomorphic because they have high frequency (96.8\%). On the other hand, the A allele at HEL9 locus cannot be categorized as monomorphic, because the frequency is only $92.9 \%$.

The abnormal colour patterns were found in all locations, except for Tabanan district. The highest number of abnormal colour patterns was found at Klungkung district, especially at Nusa Penida Island. In Klungkung district, the percentage of abnormal colour patterns was 53.6\%, while in Quarantine Centre the percentage was 56\%. The most common abnormal colour pattern is the red or brown colour of the lower parts of the legs. It is speculated that these abnormal cattle was originated from Klungkung district, because it was quite often that Klungkung local government distributed the cattle to other districts in Bali island.

The abnormal colour patterns could be as a result of homozygous recessive genotype due to inbreeding. It is suggested that the inbreeding level at Nusa Penida Island (Klungkung district) is quite high because this island is closed for Bali cattle from outside of the island. PAYNE and ROLLINGSON (1973) mentioned that the number of black female cattle in 1939 was $8 \%$ of the total population. On the other hand, the percentage in the Nusa Penida Island was higher (24\%). In general, the farmers do not like the cattle with abnormal colour patterns. As a result the frequency will decrease. We found no relation between the abnormal colour patterns and the polymorphism of two loci studied. This result indicates that HEL9 and INRA035 loci do not close to the marker genes for colour patterns. 
In order to obtain accurate identification, the use of allele A and B at INRA035 locus as specific marker for Bali cattle should be supported by HEL9 locus and combined by other methods that had been mentioned by NOOR et al. (2000).

\section{References}

BISHOP.M.D.; KAPPES, S.M.; KEELE, J.W.; STONE, R.T.; SUNDEN, L.F.; HAWKIN, G.A.; TOLDO, S.S.; FRIES, R.; GROSZ, M.D.; YOO, J.; BEATTIE, C.W.:

A genetic linkage map for cattle. Genetics 136 (1994), 619-639

CIAMPOLINI, R.R.; MOAZAMI-GOUDARZI, K.; VAIMAN, D.; DILLMANN，C.; MAZZANTI，E.; FOULLEY, J.L.; LEVEZIEL, H.; CIANCI, D.: Individual multilocus genotypes using microsatellite polymorphisms to permit the analysis of the genetic variability within and between Italian beef cattle breeds. J. Anim. Sci. 73 (1995), 3259-3268

HARDJOSUBROTO, W.; ASTUTI, J.M.:

Livestock handbook. [Buku pintar peternakan]. PT Gramedia Widiasarana Indonesia, Jakarta (1993). [In Indonesia]

HARTL, D.J.; CLARK, A.G.:

Principles of population genetics. S.A. Sunderland, Massachusetts (1988)

LEHMANN, T.W.; HAWLEY, F.H.; COLLINS, F.H.:

An evaluation of evolutionary constraints on microsatellite loci using null alleles. Genetics 144 (1996), $1155-1163$

LEVINSON, G.; GUTMAN, G.A.:

Slipped-strand mispairing : a major mechanism for DNA sequence evolution. Mol. Biol. Evol. 4 (1987), 203-221

LI, W.H.; GAUR, D.:

Fundamentals of molecular evolution. S,A. Sunderland, Massachusetts (1991)

MARTOJO, H.:

Breeding and conservation of Bali cattle for supporting national livestock production development. [Upaya pemuliaan dan pelestarian sapi Bali untuk menunjang pembangunan peternakan secara nasional]. Proceeding of national seminar on Bali cattle. Udayana University, Denpasar (1990), A-35A-41 [In Indonesia]

MASUDANA, I.:

The population development of Bali cattle within the last 10 years (1980-1990) in Bali Island. [Perkembangan sapi Bali di Bali dalam sepuluh tahun terakhir (1980-1990)]. Proceeding of national seminar on Bali cattle. Udayana University, Denpasar (1990), A-11-A-30 [In Indonesia]

NAMIKAWA, T.; OTSUKA, J.; MARTOJO, H.:

Coat colour variations of Indonesian cattle. The origin and phylogeny of Indonesian native livestock (Part III): Morphological and genetically investigations on the interrelationship between domestic animals and their wild forms in Indonesia. The Research Group of Overseas Scientific Survey. (1982), 31-34

NATIONAL RESEACH COUNCIL:

Little-known Asian animals with a promising economic future. National Academic Press, Washington, D.C. (1983)

NEI, M.:

Molecular evolutionary genetics. Columbia University Press, New York. (1987)

NEI, M.; KUMAR, S.:

PANE, I.:

Molecular evolution and phylogenetics. Oxford University press, New York. (2000)

Productivity and breeding of Bali cattle. [Produktivitas dan breeding sapi Bali]. Proceeding of national seminar on Bali cattle. Hasanuddin University, Ujung Pandang (1991), 50-69 [In Indonesia].

PAYNE, W.J.A; ROLLINGSON, D.H.L.:

Bali cattle. World Anim. Rev. 7 (1973), 13-21

PAYNE, W.J.A.; HODGES, J.:

Tropical cattle: origin, breeds and breeding policies. Blackwell Science. (1997)

SASTRADIPRAJA, D.:

Bali cattle internal potency as one of germplasm for supporting national beef cattle development. [Potensi internal sapi Bali sebagai salah satu sumber plasma nutfah untuk menunjang pembangunan peternakan sapi potong dan ternak kerja secara nasional]. Proceeding of nasional seminar on Bali cattle. Udayana University, Denpasar (1990). [In Indonesian].

NOOR, R.R.; MULADNO; BENYAMIN, B.; HEDAH, Z.; HERLIANTIN: 
The purity test of Bali cattle using protein, DNA microsatellite, hair structure and chromosome analyses. [Uji kemurnian sapi Bali melalui protein, DNA mikrosatelit, struktur bulu dan kromosom]. Research Report. Faculty of Animal Science IPB and Artificial Insemination Center Singosari. Bogor. (2000). [In Indonesia].

VAIMAN, D.; MERCIER, D.; MOAZAMI-GOUDARZI, K.; EGGEN, A.; CIAMPOLINI, R.; LEPIGLE, A.; VERMALA, R.; KAUKINEN, J.; VARVIO, S.L.; MARTIN, P.; LAVEZIEL, H.:

A set of 99 cattle microsatellites : characterization, synteny mapping and polymorphism. Mammalian Genome 5 (1994), 288-297

WINAYA, A.:

The use of microsatellite markers for detecting polymorphism and phylogeny analyses of cattle genome. [Penggunaan penanda molekuler mikrosatelit untuk deteksi polimorfisme dan analisis filogenetik genom sapi. MSc. Thesis. Bogor Agricultue University. Bogor. (2000). [In Indonesia].

Received: 2003-07-11

Accepted: 2003-09-24

Authors' addresses

EKO HANDIWIRAWAN, MSc.

Pusat Penelitian dan Pengembangan Peternakan

Jalan Raya Pajajaran

Bogor

Indonesia

RONNY RACHMAN NOOR, PhD, MULADNO, PhD

Fakultas Peternakan

Institut Pertanian Bogor

Kampus IPB Darmaga

Bogor 16680

Indonesia

Prof. Dr. habil. LUTZ SCHÜLER*

Institut für Tierzucht und Tierhaltung mit Tierklinik der

Martin-Luther-Universität Halle-Wittenberg

Adam-Kuckhoff-Straße 35

D-06108 Halle

Germany

E-Mail: schueler@landw.uni-halle.de

* Corresponding author 